\title{
Adrenocortical carcinoma
}

INSERM

\section{Source}

INSERM. (1999). Orphanet: an online rare disease and orphan drug data base.

Adrenocortical carcinoma. ORPHA:1501

Adrenocortical carcinoma (ACC) is a cancer that arises from the adrenal cortex. 